\title{
INTRAPLATE SEISMICITY IN TOHOKU AND HOKKAIDO AND LARGE INTERPLATE EARTHQUAKES: A POSSIBILITY OF A LARGE INTERPLATE EARTHQUAKE OFF THE SOUTHERN SANRIKU COAST, NORTHERN JAPAN
}

\author{
Tetsuzo Seno \\ Geophysical Institute, Faculty of Science, \\ University of Tokyo, Tokyo, Japan \\ (Received February 14, 1978; Revised August 14, 1978)
}

Historical seismicity data since the year 1850 in Tohoku and Hokkaido, northern Japan, show a spatial and temporal correlation between intraplate seismicity in the land area and occurrence of large interplate earthquakes along the Japan and Kuril trenches. In the continental lithosphere adjacent landward to the rupture zones of recent large interplate earthquakes, almost all the earthquakes of magnitude 6.0 and above occurred during the periods from the 50 years before to the 10 years after the occurrence of the large interplate events. A simple statistical test shows that this correlation is significant at a $99.5 \%$ confidence level. During the period for the last 20 years, a group of intraplate earthquakes occurred in middle Tohoku with no large interplate earthquake seaward of their epicentral locations; this suggests a possibility of a large interplate event off the southern Sanriku coast in the near future. We examine other geophysical data to rate the possibility. All the examined data, i.e., historic and recent seismicity off the Sanriku, and crustal deformation revealed by the geodetic work, support the possibility of occurrence of a large event off the southern Sanriku in the near future. Source parameters are estimated for this expected event; they are conformable to those of recent large interplate events along the Japan and Kuril trenches. We can use the hypothesis on the correlation between intraplate seismicity and large interplate earthquakes as a criterion for forecasting the land area of high seismic risk for intraplate events as well as a criterion for forecasting a rupture zone of an impending large interplate earthquake. This may be of significance for instrumentation to detect various kind of phenomena associated with imminent intraplate and/or interplate earthquakes.

\section{Introduction}

Stress states in the continental crust of island arcs are dominated by the 
tectonic force due to the interaction between the continental and the oceanic plates (e.g., Sugimura and Uyeda, 1973). Almost all the earthquakes in the continental plate margin along the Japanese island arc occur with a compressional axis of focal mechanism approximately in the direction of relative plate motion (Honda et al., 1967; ICHIKAWA, 1971; SHIONo, 1977; TAKAGI and HirASAWA, 1977); these earthquakes are probably due to the compressive force caused by the interaction between the plates. Coupling of the plates along the plate interface and their decoupling at the time of large interplate earthquakes should be an important factor to control the stress state in the crust along the continental plate margin (Mogr, 1969, 1970; SHImazaki, 1976, 1978; Seno, 1979). Therefore, it is interesting to study a correlation between intraplate seismicity and occurrence of large interplate earthquakes along the consuming plate margin. Previous studies on historical seismicity in southwest Japan (Ozawa, 1973; Ursu, 1974a, b; Shimazaki, 1976) show that most of the intraplate earthquakes in southwest Japan accompanied by damage occurred during from the 50 years before to the 10 years after great interplate earthquakes along the Nankai trough. Shimazaki (1976) showed that the activity before interplate earthquakes is high in the inland belt in southwest Japan and that after interplate earthquakes is high along the Japan Sea and the Philippine Sea coasts. A further investigation into distribution of intraplate seismicity in southwest Japan in connection with the rupture zones of interplate earthquakes (SENO, 1979) revealed that the activity before interplate earthquakes (preseismic activity) is high in the land area adjacent to the rupture zones of interplate earthquakes and, in contrast, the activity after interplate earthquakes (postseismic activity) is high in the marginal zones which border the preseismically active area. Recently, SHIMAZAKI (1978) studied the intraplate seismicity in Tohoku in connection with large interplate earthquakes along the Japan trench and pointed out that there are three active periods for intraplate seismicity and these periods correlate with occurrence of three large interplate earthquakes. He, however, treated the Tohoku district as a whole; thus in his statistics some intraplate earthquakes are correlated with those interplate earthquakes far from their epicentral locations and they are not necessarily located in the land area adjacent to the rupture zones of the interplate earthquakes.

In this study, we examine intraplate seismicity in Tohoku and Hokkaido, northern Japan, since the year 1850, especially, in connection with the spatial extent of the rupture zones of large historic interplate earthquakes along the Japan and Kuril trenches. For this purpose, the land area of northern Japan is divided into several zones parallel to the slip vectors of large interplate earthquakes in the length of their rupture zones. Then, in each zone, tem- 
poral correlation between intraplate seismicity and occurence of large interplate earthquakes is examined.

From the view point of earthquake prediction, regionalization of intraplate seismicity in terms of the spatial extent of rupture zones of large interplate earthquakes along the Japanese islands may provide very useful information on the location of the rupture zone of a future interplate shock and the land areas of high seismic risk. In southwest Japan, Seno (1979) pointed out that the intraplate earthquakes for the last 20 years have apparently occurred in spatial correlation with the expected rupture zone of a great future event off Tokai estimated by Ishibashi (1977). Similarly in northern Japan, recent seismicity data suggest a possibility of a large interplate earthquake off the southern Sanriku, middle Tohoku. In the latter half of this study, we shall examine other geophysical data to rate the possibility.

\section{Data}

Intraplate seismicity data used in this study are taken from "Descriptive Catalogue of Disaster Earthquakes in Japan" (UsamI, 1975) for the period before the year 1974 and the Seismological Bulletin of the Japan Meteorological Agency (J.M.A.) for the period 1974-1976. Results of reexamination of epicentral location and magnitude for historic earthquakes (UTSU, 1968; Usami and KaYANo, 1970; Hatori, 1975; ShIMAZAKI, 1978) are also referred to.

The time period treated in this study is the past 127 years (1850 to 1976). We use earthquakes of magnitude 6.0 and above. Our main concern is the severe intraplate earthquakes which cause destructive damage and most of such severe shocks are probably listed in Usami's catalogue. However, it should be noted that the extent of the damage caused by earthquakes depends on the social circumstances such as population, means of communication, and so on. Therefore certain number of earthquakes of magnitude 6.0 and above might not be listed in Usami's catalogue. It should also be noticed that there remains ambiguity for estimation of magnitude of historic earthquakes (e.g., Usami and KaYANo, 1970; Miyamura, 1977). Thus the intraplate seismicity data used in this study are more or less limited for the above reasons; however, for the past 100 years, the data are considered to be reliable enough for the present study, because the Central Meteorological Observatory began systematic collection of report on felt earthquakes all over Japan in 1880 (Usami and Hamamatsu, 1967) and because Shimazaki (1978) obtained a qualified guarantee for the detectability of earthquakes of magnitude 5.8-6.0 and above in Tohoku during this period. Therefore a statistical test for correlation will be attempted only for the past 100 years. 


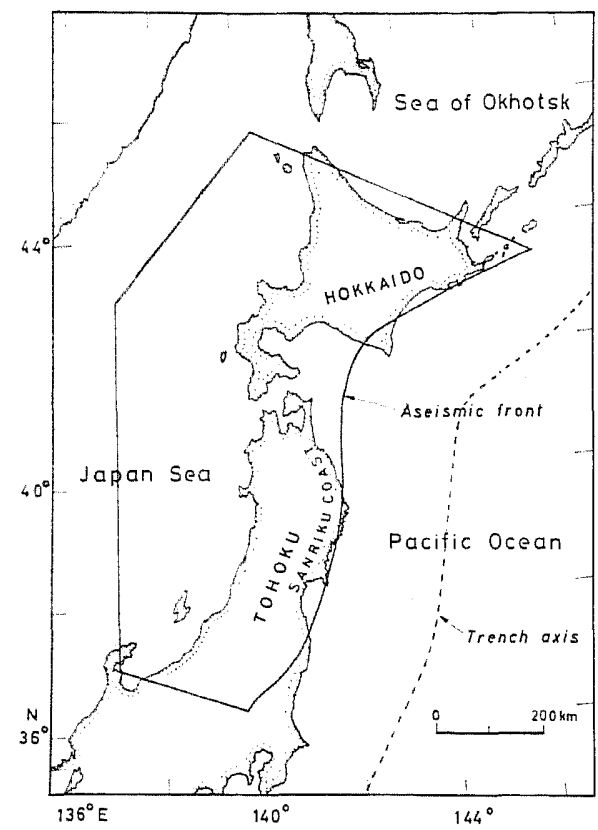

Fig. 1. The map of Tohoku and Hokkaido, northern Japan. Only the intraplate earthquakes which occur in the area indicated by the thin line are treated in this study.

All foreshocks and aftershocks are excluded in the statistics because they are not independent shocks. To select only the intraplate earthquakes in the continental lithoshere, we exclude those earthquakes which have foci deeper than $50 \mathrm{~km}$ and those which occurred oceanward of the aseismic front proposed by Yoshir (1975) (see Fig. 1). According to Yoshir $(1975,1977)$, only intraplate earthquakes occur on the continental side of the aseismic front. These procedures are similar to those in Shrmazakr (1978). Only the intraplate earthquakes which occurred within the area enclosed by the thick line in Fig. 1 are treated in this study.

The rupture zones of large interplate earthquakes off the Pacific coast of Tohoku and Hokkaido are based on the previous studies on aftershock locations, intensity, tsunami descriptions, and land deformations (KANAMORI, 1971a; Utsu, 1974a; Hatori, 1969, 1974a, b; Shimazaki, 1974b; Yoshioka and ABE, 1976; ABE, 1977; AIDA, 1977). Surface wave magnitude is referred to when available (KANAMORI, 1972, 1977; ShIMAZAKI, 1974b; YoshIOKA and $A B E, 1976 ; A B E, 1977)$; otherwise, the magnitude data are based on the Science Almanac (Tokyo Astronomical ObServatory, 1977). 


\section{Intraplate Seismicity before and after Large Interplate Earthquakes}

We shall present the intraplate seismicity $(M \geq 6.0)$ during the period 1850-1976 dividing this period into two for convenience. Figure 2 shows the intraplate seismicity during the period 1907-1976. The rupture zones of large interplate earthquakes $\left(M\right.$ or $\left.M_{s} \geq 7.7\right)$ during this period are shaded. The earthquakes shown are: the Sioya-Oki events (triplet, $M_{s}=7.4,7.7$, and 7.8) of May 23, November 5, and November 5, 1938, the Tokachi-Oki event $\left(M_{s}=8.3\right)$ of March 4, 1952, the Tokachi-Oki event $\left(M_{s}=7.9\right)$ of May 16,

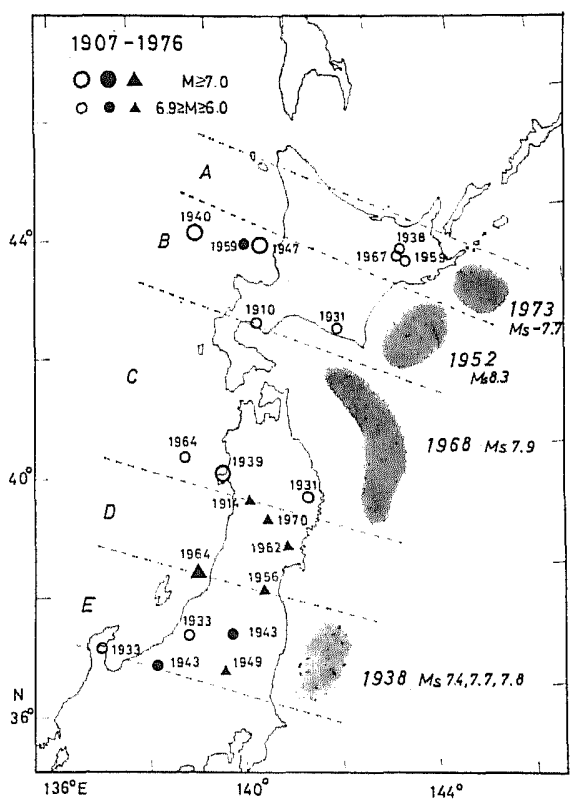

Fig. 2. Spatial distribution of intraplate earthquakes $(M \geq 6.0)$ in Tohoku and Hokkaido during the period 1907-1976. Shaded areas show the rupture zones of large interplate earthquakes during this period. The land area is divided into zones $\mathrm{A}, \mathrm{B}, \mathrm{C}, \mathrm{D}$, and, $\mathrm{E}$ parallel to the slip vectors of recent large interplate earthquakes. The open and closed circles denote the intraplate earthquakes which occurred during the 50 years before and the 10 years after large interplate earthquakes seaward of their epicenters, respectively. The triangles denote intraplate earthquakes which cannot be correlated with any large interplate event up to the present.

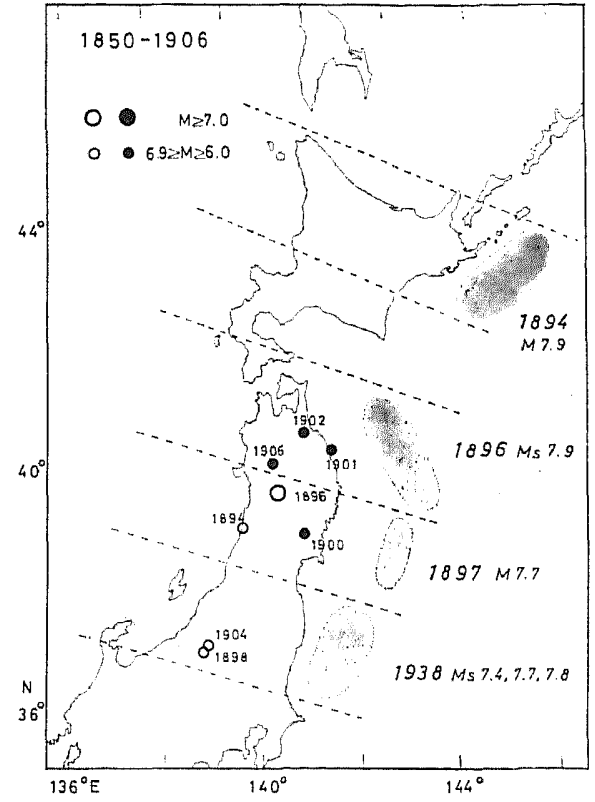

Fig. 3. Spatial distribution of intraplate earthquakes $(M \geq 6.0)$ in Tohoku and Hokkaido during the period 1850-1906. Shaded areas show the rupture zones of large interplate earthquakes. The open and closed circles denote intraplate earthquakes in the same manner as in Fig. 2 . 
1968, and the Nemuro-Oki event $\left(M_{s} \sim 7.7\right)$ of June 17, 1973. The Sanriku earthquake $(M=8.3)$ of March 3, 1933 is not shown in this figure because this event was a normal fault type of mechanism and cannot be regarded as an interplate event (KaNAMORI, 1971b). The Kinkazan-Oki event $(M=7.7)$ of November 3,1936 is not also shown because the magnitude of this event is likely to be overestimated (UTSU, 1974a). It can be reestimated to be 7.4 on the basis of source dimension of the tsunami caused by this event (HATORI, 1969).

We divide the district of Tohoku and Hokkaido into zones A, B, C, D, and, E parallel to the slip vectors of these interplate events in the spatial extent of their rupture zones (Fig. 2). The average values of the slip vectors are assumed to be $\mathrm{N} 60^{\circ} \mathrm{W}$ along the Kuril trench and $\mathrm{N} 70^{\circ} \mathrm{W}$ along the Japan trench (KanAMORI, 1971a; SHIMAZAKI, 1972, 1974b; ABE, 1977). In each divided zone, the intraplate earthquakes which occurred landward of the rupture zone of an interplate earthquake during the 50 years before its occurrence are denoted by the open circles; those which occurred during the 10 years after the interplate earthquake are denoted by the solid circles, and others are denoted by the solid triangles (Fig. 2). We can see from this figure that except those in zone $\mathrm{D}$, most of the intraplate events occurred during the periods from the 50 years before to the 10 years after the interplate earthquake in each zone. That is, except those in zone $\mathrm{D}$, only one event, i.e., the 1949 event in zone $\mathrm{E}$ is denoted by the solid triangle; however, it is noticed that this event occurred only 11 years after the 1938 Sioya-Oki events. In zone $\mathrm{D}$ are distributed the intraplate events which have no large interplate earthquake oceanward of their epicentral locations. This point will be discussed later.

Figure 3 shows the intraplate seismicity during the earlier period 1850 1906. Rupture zones of large interplate earthquakes are shaded. The earthquakes shown are: the Nemuro-Oki event $(M=7.9)$ of March 22, 1894, the Sanriku-Oki event $\left(M_{s}=7.9\right)$ of June 15,1896 , the Sendai-Oki event ( $M=$ 7.7) of August 5, 1897, and the Shioya-Oki events in 1938.

We divide the land area into the zones parallel to the slip vectors in the extent of the rupture zones of these interplate earthquakes (Fig. 3). All the intraplate earthquakes occurred during the periods from the 50 years before to the 10 years after the interplate earthquakes in each zone. No intraplate event is found in the zone adjacent landward to the rupture zone of the 1894 Nemuro-Oki earthquake; this may suggest the incompleteness of the seismicity data in this zone during this period. In this zone, however, occurred two intraplate events of magnitude 5.9 on September 20,1863 and on February 28,1874 in the Japan Sea off west Hokkaido and these events may be regarded as the preseismic activity of the 1894 Nemuro-Oki earthquake. 
From Fig. 2 and Fig. 3, we cannot see any significant difference in distribution of intraplate seismicity between before and after the interplate earthquakes. In contrast, in southwest Japan it shows a remarkable difference between the preseismic and postseimic stages (SHIMAZAKI, 1976; SENO, 1979). This may suggest a difference in the mechanism of postseismic activity between southwest Japan and northern Japan; this point will be discussed in the later section.

\section{Correlation}

We have shown that all the intraplate earthquakes $(M \geq 6.0)$ during the period 1850-1976 except those in zone D occurred landward of the rupture zones of large interplate earthquakes prior to and after their occurrence. We now examine whether this phenomenon is statistically significant or not. For the test of correlation, we treat the period for the past 100 years (18771976) because the seismicity data are reliable for this period and because the recurrence time of large interplate earthquakes off the Pacific coast of Tohoku and Hokkaido is approximately 100 years (e.g., UTSU, 1968). Figure 4 shows the time sequence of occurrence of intraplate events in zones $B, C$, and $E$. Let us assume that intraplate events occur independently each other and randomly in each zone; then, we can define a Bernouill trial with a possibility of success of 0.6 as follows. If an intraplate event which can occur randomly during the past 100 years occur during the period from the 50 years before to the 10 years after an interplate earthquake in the same zone, we

B

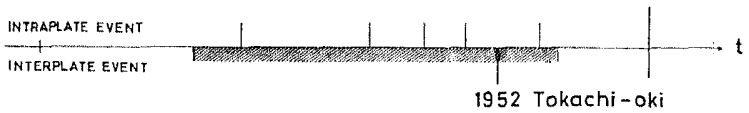

C

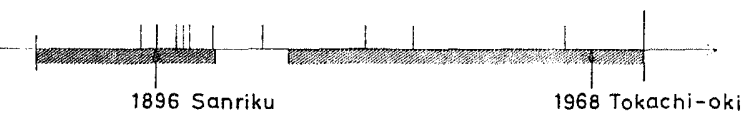

E

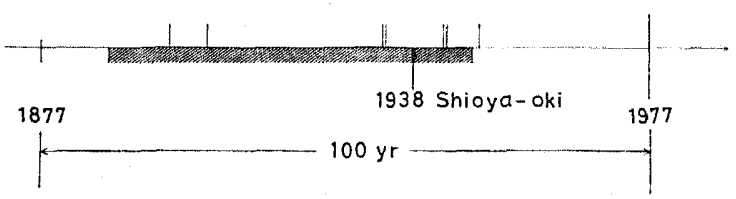

Fig. 4. Temporal distribution of intraplate and interplate earthquakes in zones $\mathrm{B}, \mathrm{C}$, and $\mathrm{E}$ for the last 100 years. Bars on the upper side of the time axis indicate intraplate events and arrows on the lower side large interplate events. Shaded portions show the periods from the 50 years before and the 10 years after large interplate events. 
call this event success, and otherwise failure. We shall calculate the probability of occurrence of more than certain number of successes in $N$ times Bernouill trials, where $N$ is the number of intraplate events observed for the past 100 years. We calculate this probability only for the events in zones $A$, $\mathrm{B}$, and $\mathrm{E}$ because in zone $\mathrm{C}$, most of the past 100 year interval is occupied by the preseismic and postseismic stages of the 1896 and 1968 events (Fig. 4), and in zone $\mathrm{D}$, there remains a possibility of occurrence of a large interplate event in the future as will be discussed later.

In zone $A$, there are 3 success events, in zone $B, 5$ success events, and in zone $\mathrm{E}, 6$ success events and one failure, thus we calculate the probability of more than 14 successes in 15 trials; this probability is calculated as follows:

$$
{ }_{15} \mathrm{C}_{14}(0.6)^{14}(0.4)^{1}+{ }_{15} \mathrm{C}_{15}(0.6)^{15}=0.0052 \text {. }
$$

This means that the correlation between intraplate seismicity and interplate earthquakes in Tohoku and Hokkaido is significant at a confidence level of 99.5 per cent.

\section{Possibility of a Large Interplate Earthquake off the Southern Sanriku Coast}

\subsection{Previous investigations}

Those intraplate events in zone D are not correlated with any large interplate earthquake in Fig. 2, although some investigators (MoGI, 1969; SHIMAZAKI, 1978) discussed them in connection with the 1968 Tokachi-Oki event. If we accept a hypothesis that intraplate events occur in a spatial and temporal correlation with interplate earthquakes as discussed in section 4 , this suggests a possibility of occurrence of a large interplate event off the southern Sanriku coast, Miyagi prefecture in the near future. Thus it is interesting to examine other seismological, geodetic, and geomorphological data to rate the possibility or to delineate, if possible, the rupture zone of a future event. We first discuss some previous investigations which noticed a high seismic risk off the Pacific coast of Tohoku.

Mogr (1968) studied the recent seismic activity in and near Japan and noted that the former five great earthquakes (the 1944, 1946, 1933, 1952, and 1968 events) occurred to fill gaps in activity for large earthquakes of magnitude 7.0 and above. He estimated on the basis of the seismic activity for the last 30 years (1939 to 1968) that there is a gap in activity for earthquakes of magnitude 7.0 and above in a wide area off southern Honshu to southern Tohoku and that large seismic events may occur in this region in the near future.

KELLEHER et al. (1973) delineated several areas of seismic risk along the major consuming boundaries on the basis of the several possible criteria for 
forecasting the locations of future large interplate earthquakes. For Japanese seismic zone, he pointed out two sites that are considered to experience future large shocks; they are the areas off the Pacific coast of Tohoku and near the Pacific coast of southern Honshu, which are contained mostly in the region estimated by Mogr (1968).

The estimations of seismic risk for the region off the Pacific coast of Tohoku by these authors are based on the first set of criteria proposed by Kelleher et al. (1973), i.e., this area is a part of a major shallow seismic belt characterized predominantly by thrust faulting and has not ruptured for at least last 30 years. However, this does not rule out the possibility that the relative motion between the plates is taken up mainly by aseismic slip or by small-magnitude earthquakes in this portion of the plate boundary. Furthermore, because the region of seismic risk estimated by them is spreading into a very wide area, the location of a future shock is obscure.

NAGUMO (1973) investigated activation modes between focal regions of large earthquakes along the Japanese seismic zone. He estimated several areas which are likely to be activated in the near future; one of them is the area off the southern Sanriku coast, Miyagi prefecture, which is a gap for large earthquakes. The area of seismic risk examined in this study is approximately contained within the area pointed out by NAGUMO (1973).

UTSU (1974a) noticed a gap for earthquakes of magnitude 6.5 and above since the year 1926 off the southern Sanriku coast. However, he did not conclude that this region is a area of high seismic risk because the type of the pattern of occurrence of earthquakes in and near the gap is uncertain.

Though the previous investigations discussed above noticed a gap in activity for major or great earthquakes off the Pacific coast of Tohoku, their estimation for seismic risk remains uncertain because the examined data were quite limited. Since more detailed data are available at present, we shall examine these data to rate the seismic risk off the southern Sanriku in the following subsections.

\subsection{Historic and recent seismicity off the Sanriku coast, Tohoku}

The shaded areas of Fig. 5 show rupture zones of large interplate earthquakes $(M \geq 7.5)$ off the Pacific coast of Tohoku for the last 50 years. The earthquakes presented are: the Aomori-Oki event $(M=7.6)$ of March 9, 1931, the Kinkazan-Oki event $(M=7.4)$ of November 3, 1936, the Shioya-Oki events in 1938, the Sanriku-Oki event $(M=7.5)$ of March 21, 1960, the Tokachi-Oki event in 1968, and its aftershock-like event, the Iwate-Oki $\left(M_{s}=7.2\right)$ of June 12, 1968. The aftershock area of the Sanriku earthquake of March 3, 1933 (KANAMORI, 1971b) is indicated by the broken line in this figure. This shock is a normal faulting which took place over the entire 


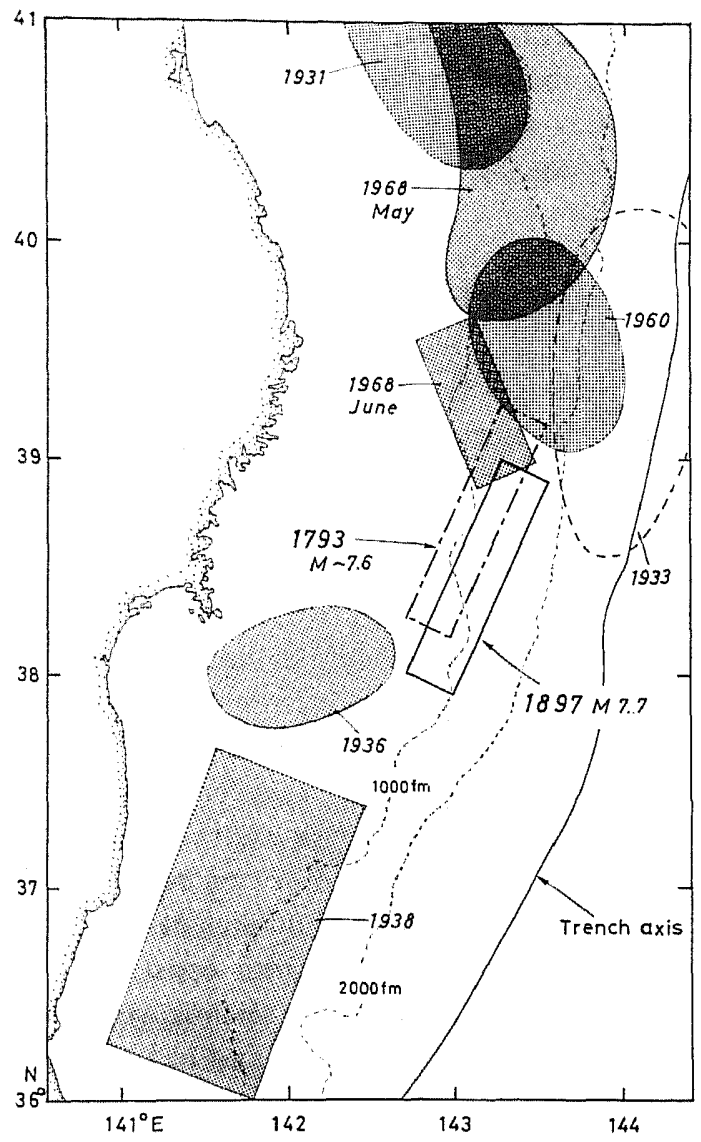

Fig. 5. Rupture zones of large interplate earthquakes $(M \geqslant 7.5)$ off the Sanriku coast, Tohoku, for the past 50 years. The aftershock area of the 1933 Sanriku earthquake is indicated by the broken line. The fault area that ruptured in 1793 and in 1897 are indicated by the chain and solid lines, respectively (AIDA, 1977).

thickness of the oceanic lithosphere (KANAMORI, 1971b). Therefore it has not probably relieved the strain accumulated along the plate interface; on the contrary, it may have loaded the usual thrust zone to the landward of the 1933 event (KeLleHer et al., 1973; FuJIr, 1977).

This figure presents a gap in activity for large earthquakes $(M \gtrsim 7.5)$ off the southern Sanriku; thus this area satisfies the first set of criteria for forecasting the location of a future large event proposed by KELLEHER et al. (1973). It is, however, important to see whether a historic record of one or more large earthquakes along this segment is taken as evidence that large earthquake can again occur along this segment.

Studies on tsunamis generated by past large earthquakes off the Pacific 
coast of Tohoku (HATORI, 1975, 1976; AIDA, 1977) mapped two large earthquakes in this gap; these earthquakes are the event $(M=7.1)$ of February 17, 1793 and the event $(M=7.7)$ of August 5, 1897. Both earthquakes caused tsunamis of which inundation heights are 2-3 $\mathrm{m}$ along the southern Sanriku coast. The magnitude of the 1793 event is likely to be underestimated if the seismic intensity and the dimension of tsunami source area caused by this event are taken into account (Hatori, 1977, personal communication); using the empirical relation between magnitude and tsunami source dimension (HATORI, 1974a), the magnitude of this event can be reestimated as 7.7. The first motion of tsunami caused by the 1897 event recorded at the tidal

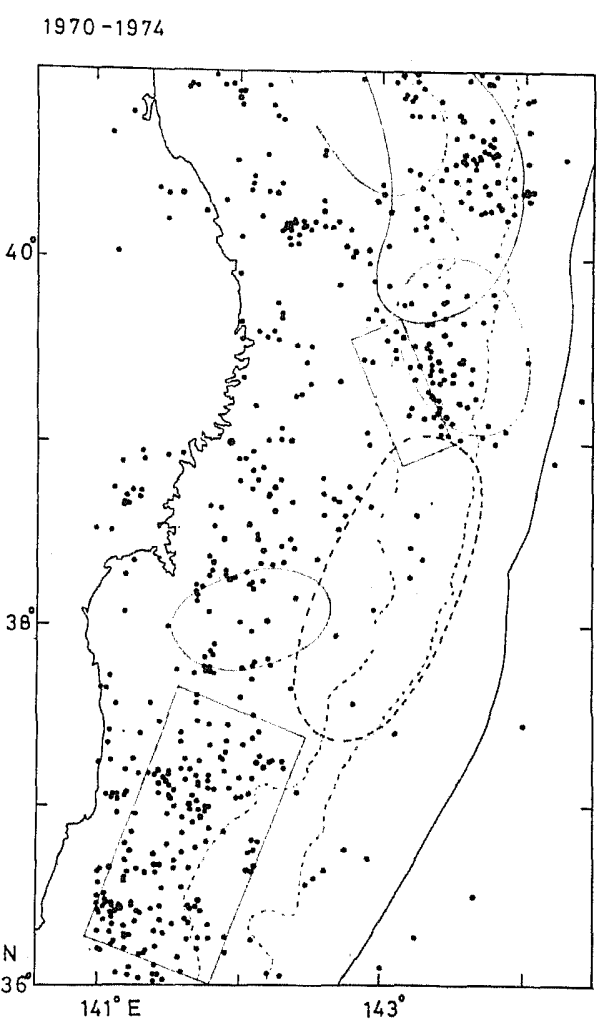

(a)
$1975-1976$

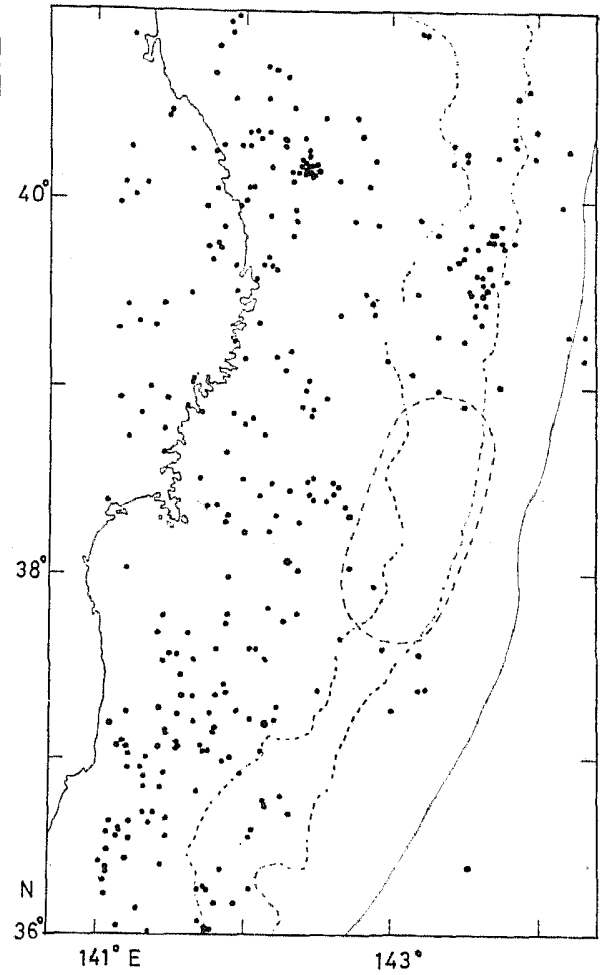

(b)

Fig. 6. (a) Epicentral distribution of recent (1970-1974) earthquakes off the Sanriku coast based on the I.S.C. Catalogue. The area of reduced level of seismicity is enclosed by the broken line. Rupture zones of large interplate events for the last 50 years are also indicated by the thin line. (b) Epicentral distribution of recent (1975-1976) earthquakes off the Sanriku coast based on the Seismological Bulletin of J.M.A. The area of reduced level of seismicity is enclosed by the broken line. 
stations, Ayukawa and Hanasaki, on the Pacific coast of northern Japan indicates that this event was a thrust type (AIDA, 1977). Since the year 1897 , no large earthquake of magnitude 7.5 and above have occurred in the zone that ruptured in 1897. Only one large event $(M=7.0)$ in 1915 is identified within or near this zone. However, the area that ruptured in 1915 is undoubtedly much smaller than that ruptured in 1897 because the inundation height of tsunami caused by this event is only $0.6-0.9 \mathrm{~m}$ along the southern Sanriku. These results indicate that the gap in activity for large earthquakes off the southern Sanriku is possibly a site to experience a large interplate earthquake in the future.

Gaps in activity for great or large earthquakes along major plate boundary may also be gaps for smaller-magnitude activity. Previous studies (INOUYE, 1965; Utsu, 1968, 1972; Mogi, 1969; Sykes, 1971; Kelleher and Savino, 1975 ) showed that extensive portions of the interior of the rupture zone remain aseismic for tens of years until the time of the main shock. Thus it is important to study activity of smaller earthquakes off the Pacific coast of Tohoku.

Epicenters of the earthquakes off the Sanriku coast during the period 1970-1974 based on the Regional Catalogue of the International Seismological Centre (I.S.C.) are plotted in Fig. 6(a). For the last two years (1975 to 1976), the I.S.C. Catalogue is not available, thus epicenters of the earthquakes off the Sanriku based on the Seismological Bulletin of J.M.A. are plotted in Fig. 6(b). These figures present an area of low level of seismic activity enclosing the zone that ruptured in 1897. This area is indicated by the broken line in these figures. During this period are distributed no earthquake of magnitude 5.0 and above within the area indicated by the broken line. For the period 1964-1969, the epicentral distribution of earthquakes off the Pacific coast of Tohoku based on the I.S.C. Catalogue also shows that extensive portions of the zone that ruptured in 1897 remained extremely calm, though there occurred a few number of earthquakes of magnitude 5.4 in 1968 and in 1969 prior to and after the 1968 Tokachi-Oki event.

It has been also pointed out that epicentral determination by the microearthquake network of Tohoku University operated since the year 1970 presents a region of reduced seismic activity far off the southern Sanriku (Research Group for Microearthquakes, Faculty of Science, Tohoku University, 1974; Faculty of Science, Tohoku University, 1976; TAkagi and HrRasawa, 1977).

Since the modern seismograph network of J.M.A. was in full operation in 1926, earthquake of magnitude over 6.0 occurred in and near the zone that ruptured in 1897 in swarm seismic activity in 1938, 1939, 1958, 1959, 1960, and 1962. Since the year 1963, no earthquake of magnitude 6.0 and above are identified within or near the zone that ruptured in 1897. 
The reduced level of seismic activity for smaller-magnitude earthquake in the area including the zone that ruptured in 1897 probably indicates that this area is likely to experience a large earthquake in the near future.

\subsection{Recent crustal deformation in Tohoku :}

Geodetic work over Tohoku has been repeated several times since the year 1894 by the Geographical Survey Institute (G.S.I.). The results of the work revealed features of crustal deformation in middle Tohoku, which are characteristic of interseismic crustal deformation along the Pacific coast of Japan, i.e., contraction in the direction perpendicular to the trench axis and oceanward tilt.

Figure 7 shows the synthesized change in height over Tohoku during the period 1900-1975 (KАTO, 1979). As clearly seen in this figure, middle Tohoku tilts towards the Pacific Ocean. Subsidence along the southern Sanriku amounts to $30 \mathrm{~cm}$. Contribution of coseismic crustal deformation due to the large earthquakes off the Pacific coast of Tohoku during this period to the change in height is at most $\pm 5 \mathrm{~cm}$ (FurII, 1977; Kato, 1979), thus it

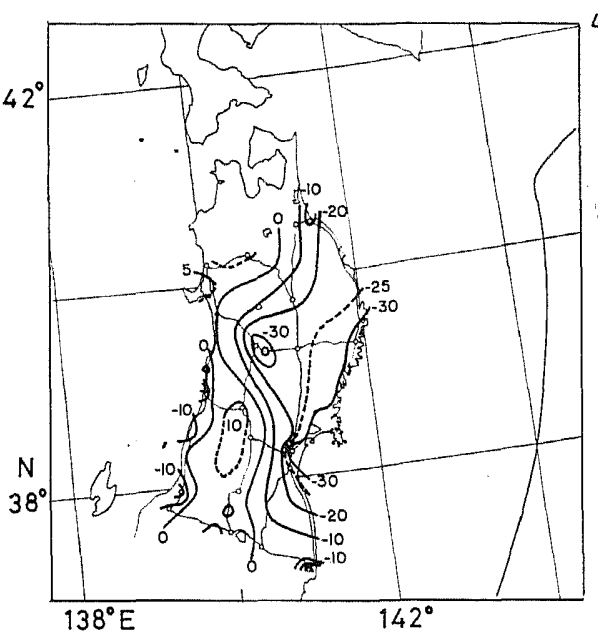

Fig. 7. Synthesized change in height over Tohoku during the period 1900-1975 (after KATO, 1979). The change is given in centimeters. It is assumed that the bench mark at Noshiro did not move during this period.

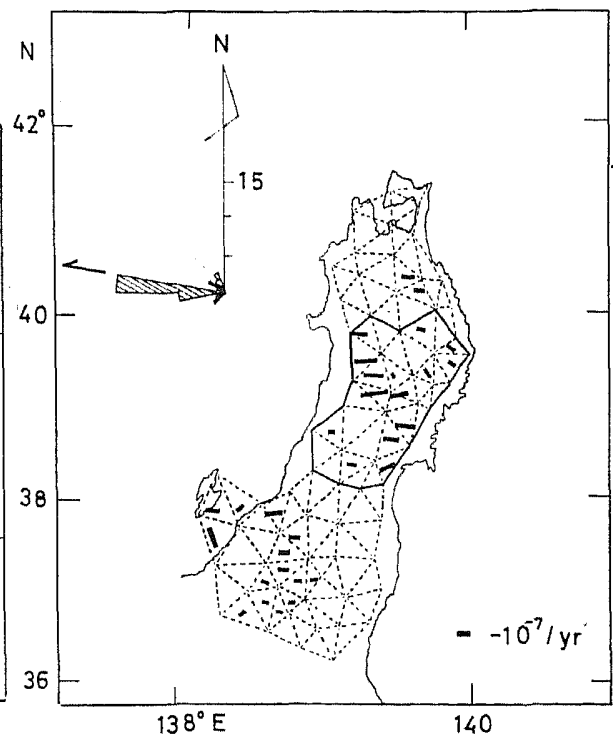

Fig. 8. Contraction principal axes of horizontal strain observed during the period from 1893, 1904 to 1962, 1963 (modified from HARADA and KASSAI, 1971). The compass rose diagram inserted at the upper left gives the azimuthal orientation of the axes; the attached arrow indicates the direction perpendicular to the trench axis. 
is negligible compared with the total change in height along the southern Sanriku. Tide gauge records at Miyako, Kamaishi, Ofunato, Onagawa, and Ayukawa, on the southern Sanriku coast indicate that the annual mean sea level has bean rising at an almost constant rate amounting to $4-6 \mathrm{~mm} / \mathrm{yr}$ for the last tens of years (Tsumura, 1971; Coastal Movements Data Center [C.M.D.C.], 1976). In contrast, the tidal record from the tide gauge station, Fukaura, on the Japan Sea coast of Tohoku shows no long-term change beyond a few centimeters in the annual mean sea level since the year 1898 (C.M.D.C.). An absolute datum for the vertical movement in Fig. 7 was determined on the assumption that the bench mark $\mathrm{J} 1$ at Noshiro, which is located $50 \mathrm{~km}$ south of Fukaura did not move during the period 1900-1975 (KATo, 1979). The rate of the mean sea level rise in the tidal record along the southern Sanriku is in reasonable agreement with the synthesized change in height (Fig. 7) if the sea level rise is causally due to the vertical crustal movement over Tohoku.

The first-order triangulation survey over Tohoku has been carried out twice, in 1894-1900 and in 1961-1963. The trend of contraction principal axes of the horizontal strain accumulated between the two surveys (HARADA and KASSAI, 1971) are shown in Fig. 8. They are nearly perpendicular to the trench axis. The rate of contraction averaged over the area indicated by the thick line in Fig. 8 is $0.6 \cdot 10^{-7} / \mathrm{yr}$.

These features of crustal deformation in Tohoku mentioned above are characteristic of interseismic crustal deformation between large earthquakes off the Pacific coast of Japan (IMAMURa, 1929; TAKeuchi and Kanamori, 1968; Mogi, 1970; Fitch and Scholz, 1971; ShimazaKi, 1972, 1974a; Yonekura and ANdo, 1973; Seno, 1977a). They are considered to be an indication that the continental lithosphere is compressed and dragged down into the asthenosphere by the subducting oceanic plate. SHIMAZAKI (1974a) successfully applied the finite-element method to a static problem of crustal deformation in eastern Hokkaido; features of crustal deformation in eastern Hokkaido have been similar to those in Tohoku, i.e., they are contraction perpendicular to the trench axis and oceanward tilt. A hypothetical tangential displacement along the plate interface down to a depth of $100 \mathrm{~km}$ with a constant rate amounting to $2.7 \mathrm{~cm} / \mathrm{yr}$ explained the general features of the observed crustal deformation well (SHIMAZAKI, 1974a). In the present study, we shall also apply the finite-element method to a two dimensional static problem of crustal deformation in Tohoku vertically cross-sectioned perpendicular to the trench axis. Recently, Kato (1979) discussed general features of vertical movement over Tohoku and applied this method to the crosssection from Kamaishi to Akita. We shall refer to his results later.

The finite-element method applied to this kind of problem has been 
adequately described elsewhere (ShIMAZAKI, 1974a; Kato, 1979). Kato (1979) contructed a finite-element grid modelling the upper side of the plate interface in a vertical cross-section of Tohoku perpendicular to the trench axis, referring to the geophysical data along this arc (YosHII, 1977). We here use his modelling except the location of the continental side limit of the grid; this boundary is set at $550 \mathrm{~km}$ inlandward from the trench axis because the intraplate earthquakes occur at most $520 \mathrm{~km}$ inlandward from the Japan and the Kuril trenches. An underthrusting of the oceanic plate is represented by a prescribed displacement given on the plate interface. Boundary conditions put on the finite-element grid are free on the upper surface which corresponds to the earth's surface, and a zero displacement on the other boundaries except where a prescribed displacement is given.

We shall compare the calculated surface deformation of the upper plate with the observed data projected onto the vertical planes under the lines $A-A^{\prime}$ and $B-B^{\prime}$ (Fig. 9). Vertical movement along the levelling route from Sendai to Sakata during the past two periods $(1894,1899$ to 1942 , and 1942 to 1973) are projected onto the vertical plane under the line A-A' (Fig. 10; lower), and those along the route from Kamaishi to Akita during the periods

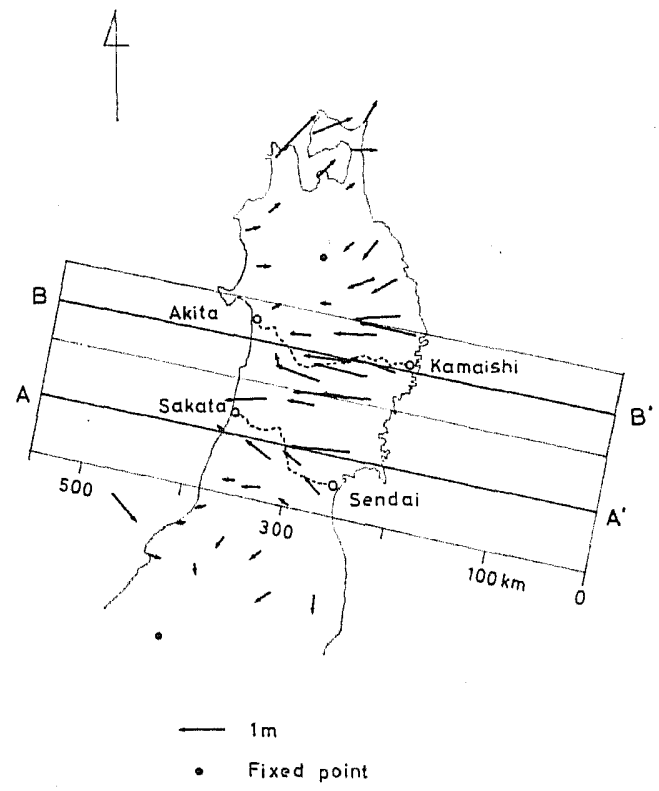

Fig. 9. Horizontal displacement of first-order triangulation points observed during the period from 1893, 1904 to 1962, 1963 (after HARADA and ISAWA, 1969). Those displacement vectors within the rectangles at the both sides of the lines $\mathrm{A}-\mathrm{A}^{\prime}$ and $\mathrm{B}-\mathrm{B}^{\prime}$ are projected onto these lines. The broken line indicates the levelling routes. Distance from the trench axis is indicated below. 


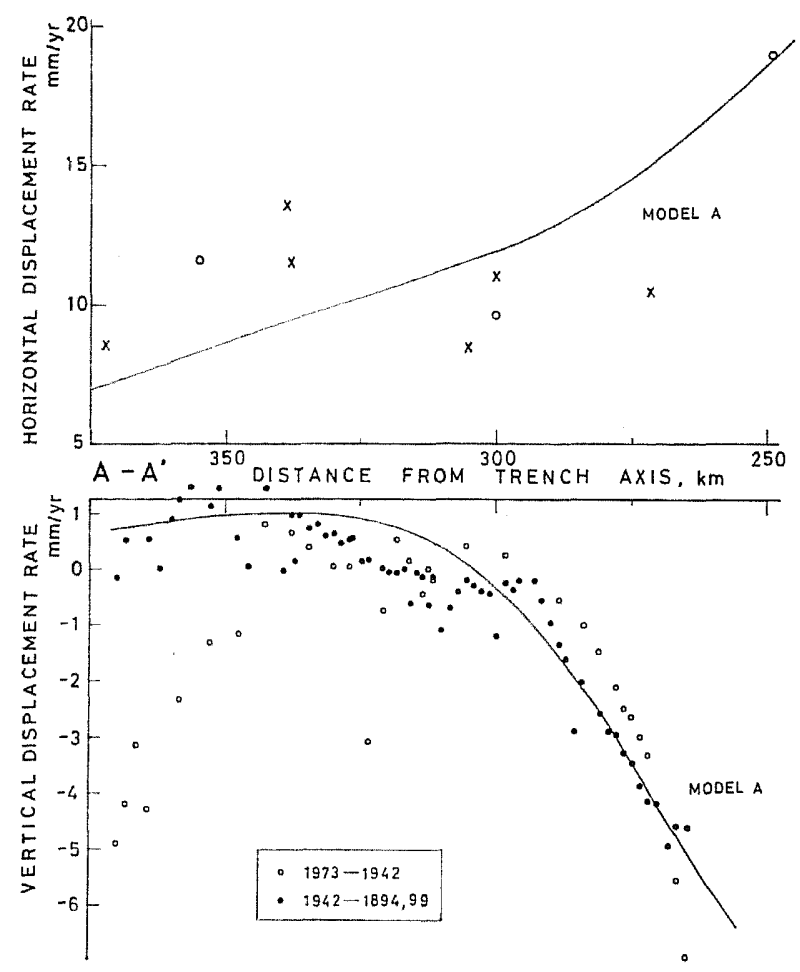

Fig. 10. Upper: Observed and computed horizontal displacement along the line $A-A^{\prime}$. The open circles and the crosses are the observed horizontal displacement of triangulation points projected from the upper and lower segments onto the line, respectively. Computed displacement for Model $\mathrm{A}$ is indicated by the solid curve. Lower: Observed and computed vertical movement along the line $\mathrm{A}-\mathrm{A}^{\prime}$. The closed and open circles denote the vertical movement of the bench marks (1894, 1899-1942, 1942-1973). It is assumed that the bench mark at Sendai is subsiding at the rate of $4-6 \mathrm{~mm} / \mathrm{yr}$. The solid curve indicates the vertical displacement computed for Model $\mathrm{A}$.

(1897, 1900 to 1933,1934 , and 1933, 1934 to 1974) onto the vertical plane under the line B-B' (Fig. 11(b)). Those displacements presented in these figures are normalized to be annual rates. Absolute datums for the vertical movement are determined on the assumptions that in the cross-section $\mathrm{A}-\mathrm{A}^{\prime}$, the bench mark at Sendai is subsiding at the rate of $4-6 \mathrm{~mm} / \mathrm{yr}$, and in the cross-section $\mathrm{B}-\mathrm{B}^{\prime}$, the bench mark at Akita did not move during this period; these assumptions seem justified because of the consistency between the synthesized change in height over Tohoku (Fig. 7) and the rate of the mean sea level rise along the Japan Sea and Pacific coasts of Tohoku.

As for the data for horizontal displacement over Tohoku, we use the horizontal displacement vectors of triangulation points as deduced from the 


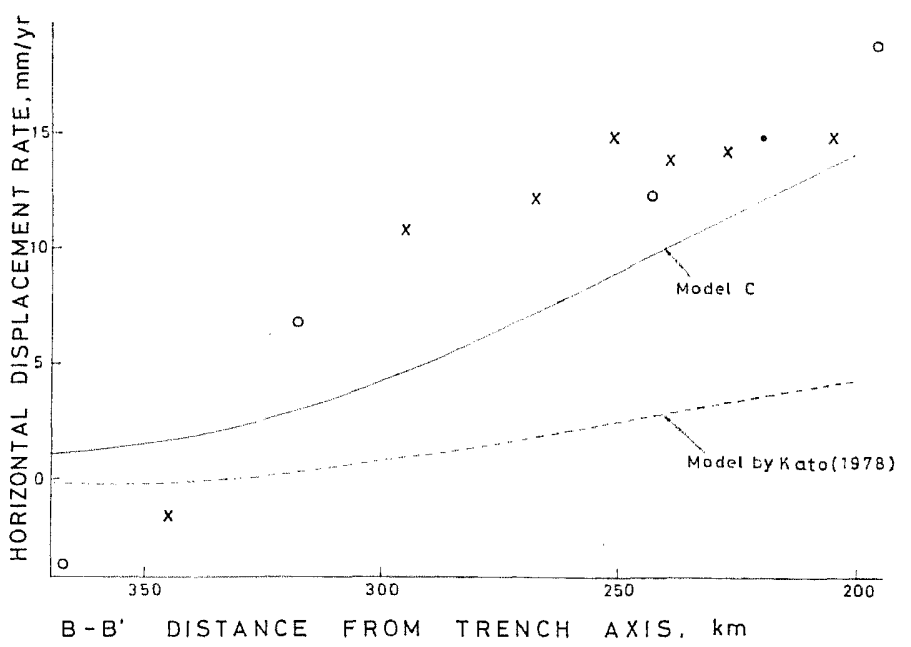

(a)

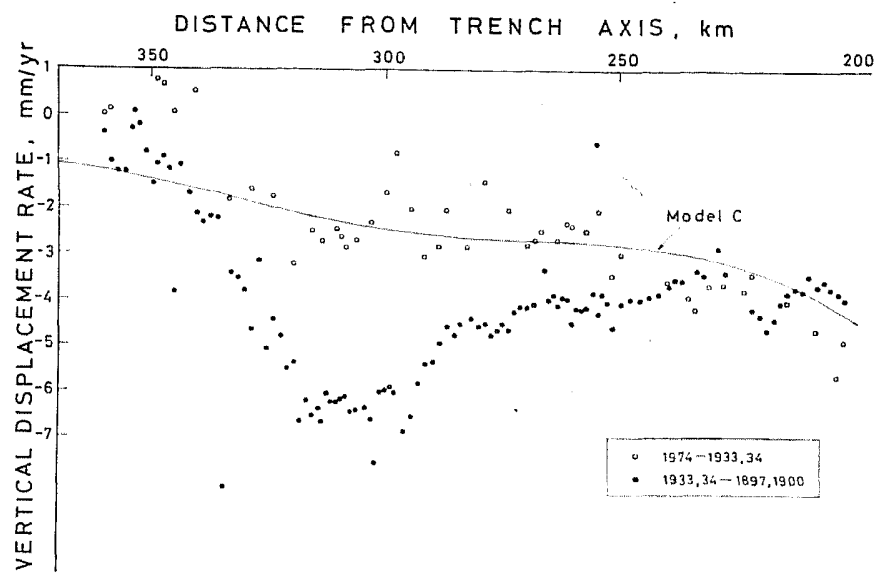

(b)

Fig. 11. (a) Observed and computed horizontal displacement along the line B-B'. The open circles and the crosses denote the observed horizontal displacement of the triangulation points projected from the upper and lower segments onto the line, respectively. The solid curve shows the horizontal displacement computed for Model $\mathrm{C}$ in the text. The broken curve shows the one computed for the model by KATO (1979). (b) Observed and computed vertical displacement along the line B-B'. The closed and the open circles denote the vertical movement of the bench marks (1897, 1900-1933, 1934, and 1933, 1934-1974). It is assumed that the bench mark at Akita did not move during the period. Computed displacement for Model $\mathrm{C}$ is indicated by the solid curve. 
first-order triangulation surveys (Fig. 9, HARADA and IsAWA, 1969). In Figs. 10 and 11 , these vectors are projected onto the lines $A-A^{\prime}$ and $B-B^{\prime}$ from the segments at the both sides of these lines (Fig. 9); they are normalized to be annual rates.

The horizontal displacement vectors were deduced on the assumption that several reference points did not move during the period between the two surveys; therefore these vectors have systematic errors such as rotation and/or divergence around the fixed points (FujITA, 1973). Thus we should compare only the trend of the horizontal displacements projected onto the lines with that computed, considerring that the points along these lines are approximately located at equi-distance from the fixed points (see Fig. 9).

In the cross-section under the line $\mathrm{A}-\mathrm{A}^{\prime}$, an uniform-tangential-dis-

(a)

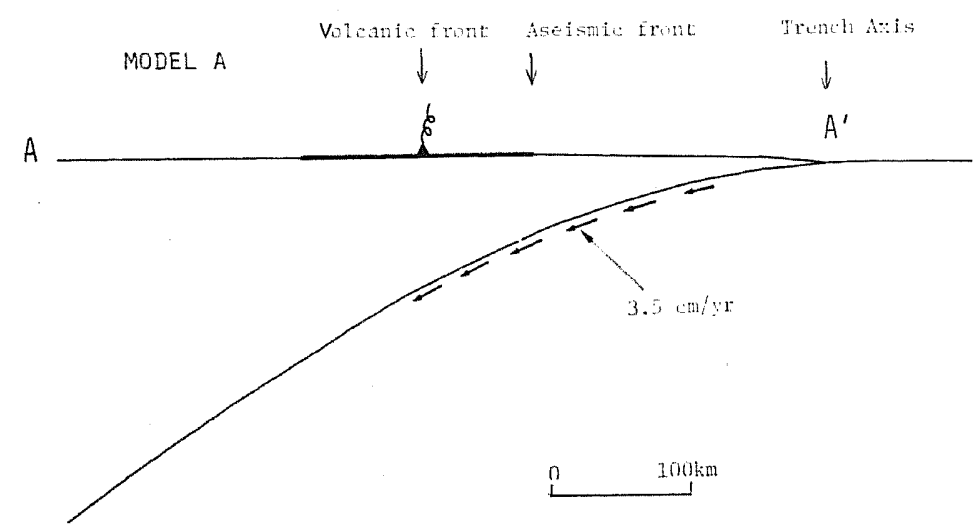

(b)

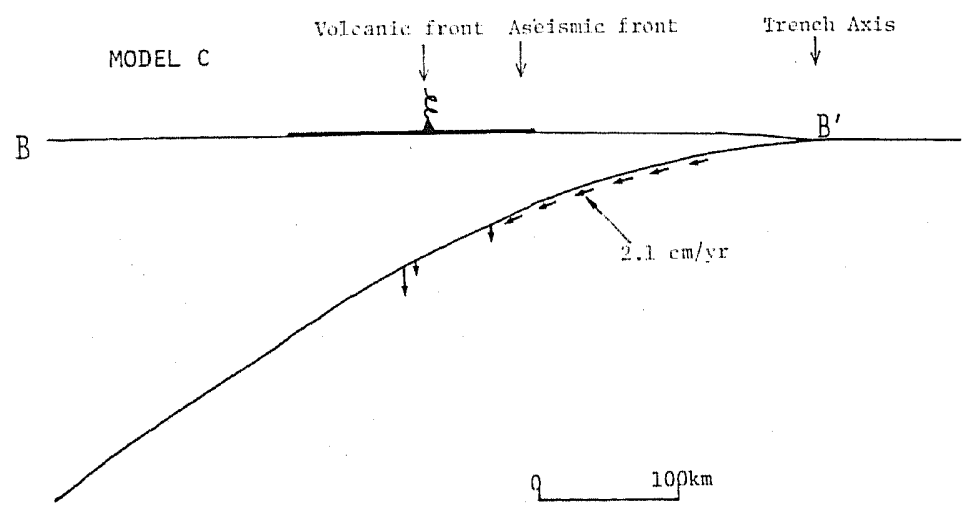

Fig. 12. (a) Uniform-tangential-displacement model (Model A) in the cross-section $\mathrm{A}-\mathrm{A}^{\prime}$. (b) Model $\mathrm{C}$ in the cross-section $\mathrm{B}-\mathrm{B}^{\prime}$. Downward displacement at the deeper plate interface is due to KATo (1979). 
placement model was obtained after trials and errors; this model assumes a displacement along the plate interface from the zone that ruptured in 1897 down to a depth of $100 \mathrm{~km}$ with a rate of $3.5 \mathrm{~cm} / \mathrm{yr}$. A depth of $100 \mathrm{~km}$ approximately corresponds to the volcanic front. This solution is illustrated in Fig. 12(a) and will be referred to as Model A. Vertical and horizontal displacement of the upper surface of the continental plate computed for this model are shown by the solid line in Fig. 10. The Model A explains the general features of crustal deformation along the line $\mathrm{A}-\mathrm{A}^{\prime}$, although the trend of the computed horizontal displacement significantly differs from that of observed at a distance of 300 to $340 \mathrm{~km}$ from the trench axis.

In the cross-section under the line $\mathrm{B}-\mathrm{B}^{\prime}$, there is some difficulty pertaining to this cross-section as was pointed out by KATo (1979). As is seen in Fig. 7, the area of subsidence extends far inlandward along the line $B-B^{\prime}$. If we attempt to explain this vertical deformation only in terms of a tangential displacement along the interface, we must assign a displacement to a depth of $120 \mathrm{~km}$ (Kato, 1979), which exceeds the depth of the volcanic front. A tangential dragging of the continental plate by the subducting oceanic plate along the interface beyond the depth of the volcanic front is probably unreasonable because a stable sliding is likely to occur there and produce a frictional heat enough to explain the high heat flow observed in the inland area of Tohoku behind the volcanic front (HASEBE et al., 1970). Kato (1979) proposed the model in the cross-section $\mathbf{B}-\mathbf{B}^{\prime}$ which assumes a downward displacement at the portion of the plate interface deeper than $65 \mathrm{~km}$ and a tangential displacement at the shallower part of the interface in the depth range from $50 \mathrm{~km}$ to $65 \mathrm{~km}$. His model explains the observed vertical movements well; however, he did not take into account the horizontal displacement along this line; thus he assigned a tangential displacement only up to the depth of $50 \mathrm{~km}$, i.e., horizontally, $20 \mathrm{~km}$ oceanward of the aseismic front. The trend of the horizontal displacement computed for his model (Model A in Kato (1979)) is indicated by the broken line in Fig. 11(a); this is disconcordant with that of observed. Therefore we modify his model at the shallower part of the interface and obtain the model which assumes a uniformtangential displacement from the zone that ruptured in 1897 down to a depth of $65 \mathrm{~km}$ along the interface with a rate of $2.1 \mathrm{~cm} / \mathrm{yr}$ and a downward displacement at the deeper part of the interface as is similar to the model by Kato (1979). This model is illustrated in Fig. 12(b) and called as Model $\mathrm{C}$ in this study. Vertical and horizontal displacement computed for Model $\mathrm{C}$ are shown by the solid lines in Figs. 11(a) and (b). This model explains the general features of the observed crustal deformation well, although the computed horizontal strain near the Japan Sea coast is much smaller than that of observed. 


\subsection{Evaluation of source parameters of the expected large event off the southern Sanriku}

In the former subsections, we delineated the location of the rupture zone of a large interplate earthquake which is likely to occur off the southern Sanriku coast in the near future. We here evaluate the source parameters of this expected event on the basis of the various data discussed in the former subsections.

From the area of the gap in activity for small- and moderate-magnitude earthquakes off the Sanriku coast (Figs. 6(a) and (b)) and that of the zone that ruptured in 1793 and in 1897 (Fig. 5), we can estimate the source dimension of the future event as follows: down dip width $W=50( \pm 20) \mathrm{km}$, length $L=150( \pm 30) \mathrm{km}$, or the fault area $S=50 \cdot 150\left(+5 \cdot 10^{3},-4 \cdot 10^{3}\right) \mathrm{km}^{2}$.

We shall next estimate the average dislocation over the fault plane at the time of the shock. As was pointed out by SHImazaki (1974a), an underthrusting movement of oceanic plate is expected to be a little larger than the displacement at the interface estimated in the former subsection because the oceanic plate is not rigid and probably deformed and because the displacement is obtained in a two dimensional static problem, not in a three dimensional one (Shimazaki, 1978, personal communication). We here assume that the latter amounts to 75 per cent of the former as assumed by SHIMAZAKI (1974a) in eastern Hokkaido; thus the underthrusting movement can be estimated as 2.8 to $4.7 \mathrm{~cm} / \mathrm{yr}$ at the interface. Historic large interplate earthquakes off the Sanriku have recurred as follows. Off the southern Sanriku occurred two large interplate earthquakes, the 1793 event and the 1897 event, with recurrence time of about 100 years. Off the middle Sanriku, two large interplate events are known unequivocally as interplate events (KANAMORI, 1971a, 1972; AIDA, 1977); they are the 1896 event $\left(M_{s}=7.9\right)$ and the 1968 Tokachi-Oki event $\left(M_{s}=7.9\right)$. Time interval between these events is 72 years. Off the northern Sanriku, Aomori prefecture, the 1677 event $(M=$ $8.1)$, the 1763 event $(M=7.8)$, and the 1856 event $(M=7.8)$ are identified as large interplate shocks (HATORI, 1975; UTsU, 1972; AIDA, 1977). Northern portion of the 1968 Tokachi-Oki event may also share its rupture zone with these historic events. Time intervals between these events are 80 to 100 years (86, 93, and 102 years). These facts indicate that the recurrence time of large ineterplate earthquakes off the Sanriku is approximately 70 to 100 years. As 80 years has past since the last event in 1897 off the southern Sanriku, we expect that the future large event is likely to occur during the 20 years to come. Therefore, the average dislocation $\bar{u}$ of the future event can be estimated as follows:

$$
\begin{aligned}
\bar{u} & =(80-100) \text { years } \cdot(2.8-4.7) \mathrm{cm} / \mathrm{yr} \\
& =2.2-4.7(3.5 \pm 1.2) \mathrm{m}
\end{aligned}
$$


The seismic moment $M_{\mathrm{o}}$, stress drop $\sigma$, and strain drop $\varepsilon$ are estimated by the following equations (e.g., AKI, 1966):

$$
M_{\mathrm{o}}=\mu \bar{u} S, \quad \sigma=(8 / 3 \pi) \mu \bar{u} / W, \quad \varepsilon=\sigma / \mu,
$$

where $\mu$ is the rigidity, which is assumed as $3.5 \cdot 10^{11} \mathrm{dyne} / \mathrm{cm}^{2}$. We obtain $M_{\mathrm{o}}=0.9(+1.2,-0.6) \cdot 10^{28} \mathrm{dyne} \cdot \mathrm{cm}, \sigma=21(+26,-12)$ bars, and $\varepsilon=0.6$ $(+0.7,-0.3) \cdot 10^{-4}$.

These source parameters estimated above are comformable to those of the recent large interplate earthquakes off the Pacific coast of Tohoku and Hokkaido (Kanamori, 1971a; Shimazaki, 1974b; ABe, 1977), though the reader must be aware of the uncertainties of a factor of 2 .

\section{Discussion}

\subsection{Preseismic activity of intraplate earthquakes}

We notice that the zone where the intraplate earthquakes denoted by the solid triangles in Fig. 2 occur just coincides with the area where the interseismic crustal deformation over Tohoku is predominant in Figs. 7 and 8. In the former section 5.4, major portions of the crustal deformation over middle Tohoku are interpreted in terms of underthrusting movement of the oceanic lithosphere; thus we can understand that the high seismic activity over middle Tohoku on the basis of strain accumulation within the continental plate margin due to the dragging by the oceanic plate. A part of contraction in the land area will be relieved at the time of or after an interplate earthquake and the other remaining portion will be stored in the crust. After many cycles of loading and unloading of the continental plate margin by the subducting oceanic plate, intraplate earthquakes will take place where the local stress in the crust exceeds the fracture strength of the crust. This provides an explanation for the preseismic activity in the area landward of the thrust zone of an impending large interplate earthquake. This area will be characterized by the features of interseismic crustal deformation, i.e., contraction perpendicular to the trench axis and oceanward tilt. The mechanism for preseismic activity proposed above is almost similar to that proposed by SHIMAZAKI $(1976,1978)$, although he did not refer to the spatial extent of the interseismic crustal deformation in connection with the specific rupture zones of large interplate earthquakes.

A schematic diagram of change in local stress in the land area proposed by Shimazaki (1978) is shown in Fig. 13 [modified from Shimazaki (1978)]. The change in local stress consists of short- and long-period components; a long-term stress increase, whose rate is denoted by $a$, is suddenly relieved due to occurrence of an intraplate earthquake and a short-term stress increase, 


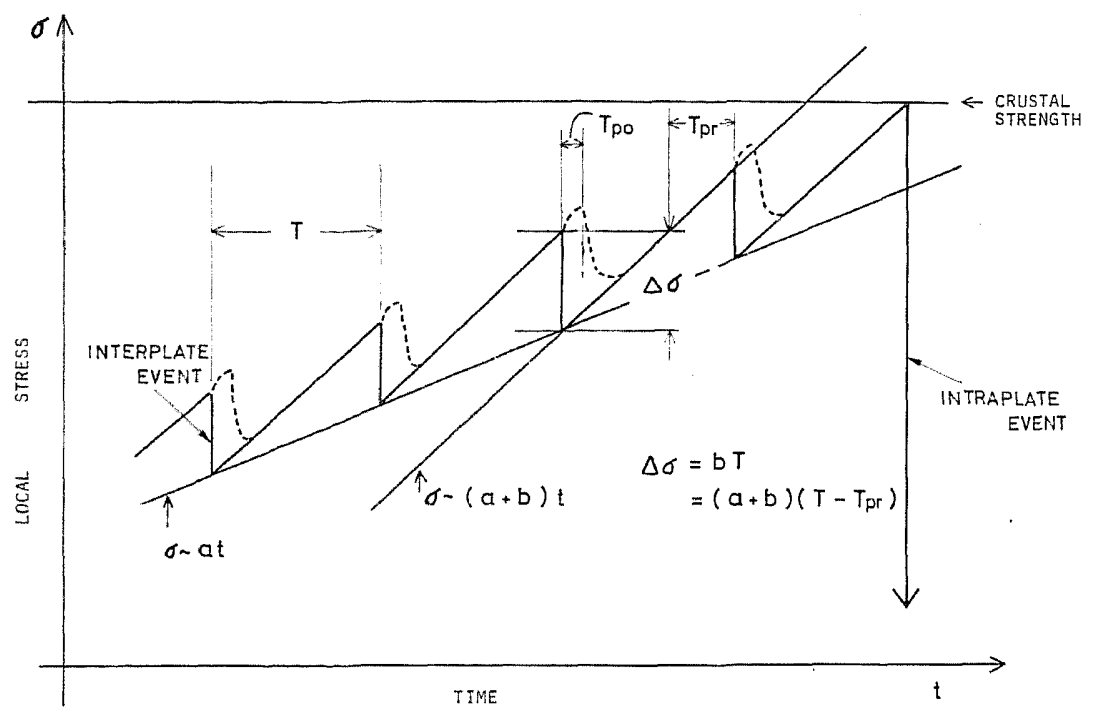

Fig. 13. Hypothetical change in local stress in time modified from Fig. 4 in Shimazaki (1978).

whose rate is denoted by $b$, is periodically relieved by occurrence of interplate earthquakes. According to ShImAzAKr (1978), there is a relation:

$$
T_{p r} /\left(T-T_{p r}\right)=a / b,
$$

where $T_{p r}$ is the duration time of preseismic activity and $T$ is the recurrence time of large interplate events. In southwest Japan, ShImazakr (1978) estimated the value $b$ as $0.2 \mathrm{bar} / \mathrm{yr}$, using Eq. (3) and assuming the value $a$ as $0.1 \mathrm{bar} / \mathrm{yr}$. In Tohoku, he estimated the value $a$ as $0.01-0.03 \mathrm{bar} / \mathrm{yr}$ assuming that the value $b$ in Tohoku is the same as that in southwest Japan and with the $T_{p r}$ of 5 years in his results (1978), and discussed that this small value $a$ in Tohoku compared with that in southwest Japan is concordant with the low level of activity of Quaternary geologically active faults in Tohoku (MATsuda, 1973). We obtained $T_{p r}$ of 50 years in Tohoku in section 4, contrary to that estimated by SHIMAZAKI (1978). Using the Eq. (3) and assuming $T$ as 100 years in Tohoku, we obtain a relation $a=b$. There is a reason to believe that the value $b$ is far smaller in Tohoku than that in southwest Japan because the Pacific coast of Tohoku is located far from the trench axis than that of southwest Japan; the former is approximately $200 \mathrm{~km}$ and the latter is $120 \mathrm{~km}$ in distance from the trench axis. Therefore, we reestimate the value $b$ in Tohoku from the results of horizontal deformation due to the tangential displacement at the plate interface computed in section 5.4. The rate of horizontal strain computed for Model $\mathrm{A}$ and Model $\mathrm{C}$ is approximately 
$10^{-7} / \mathrm{yr}$, thus we obtain the value $b$ as $0.03 \mathrm{bar} / \mathrm{yr}$ in Tohoku, assuming the rigidity in the crust as $3 \cdot 10^{11} \mathrm{dyne} / \mathrm{cm}^{2}$. The relation $a=b$ gives the value $a$ as $0.03 \mathrm{bar} / \mathrm{yr}$ in Tohoku; this value does not contradict with the low level of activity of the Quaternary active faults in Tohoku (MATsudA, 1973).

\subsection{Postseismic activity and co- and postseismic crustal deformation}

It was pointed out in section 3 that the activity of intraplate earthquakes in Tohoku and Hokkaido is high during the 10 years after large interplate earthquakes. The duration time of this postseismic activity is the same as that in southwest Japan (UTSU, 1974a, b; SHIMAZAKI, 1976) and that in Tohoku estimated by SHMAZAKI (1978). It is interesting to remind that the postseismically active area does not significantly differ from the preseismically active area in northern Japan (see Figs. 2 and 3, and see also SHIMAzAKI (1979)). In contrast, in southwest Japan, extensive portions of preseismically active areas are extremely quiescent after great interplate earthquakes (SENO, 1978) and the marginal zone of the preseismically active areas are postseismically active (SHIMAZAKI, 1976; SeNo, 1979). This indicates that the major portion of the strain accumulated in the land area is relieved at the time of interplate shocks in southwest Japan and, in contrast, not in northern Japan. This difference is probably due to the difference in distance between the land area and the trench or trough axis in these regions. Coseismic crustal deformation is predominant in the land area of southwest Japan (MoGI, 1970; FitCH and ScHolz, 1971; ANDo, 1975b); on the contrary, in northern Japan, it only gives a small change in crustal deformation (SHIMAzAKI, 1974b; Kasahara, 1975; Kato, 1979). At the time of the future expected shock off the southern Sanriku, only the upper one third of the plate interface on which the tangential displacement is given will elastically rebound. This would result in almost no relieving of the strain accumulated in the land area because the fault area of this shock is 120 to $160 \mathrm{~km}$ oceanward from the coast. We recall that this situation is quite similar to that observed in eastern Hokkaido. Geodetic work repeated in Hokkaido by the G.S.I. shows that eastern Hokkaido had been contracted perpendicular to the trench axis and tilted oceanward for the past 70 years before the year 1973 (e.g., SHIMAzaKI, $1972,1974 \mathrm{a}, \mathrm{b})$. In 1973 , the Nemuro-Oki interplate event $\left(M_{s} \sim 7.7\right)$ occurred off the Pacific coast of eastern Hokkaido. This event, however, did not relieve the strain accumulated in the land area; on the contrary, the Pacific coast of eastern Hokkaido subsided $5-10 \mathrm{~cm}$ coseismically (SHIMAZaKr, 1974b; Kasahara, 1975). ShImazaKi (1974b) showed that only upper one half of the plate interface elastically rebounded at the time of the mainshock. Geomorphological and geological data such as coastal terraces in the Pacific coast of eastern Hokkaido show that the rate of secular change in height of the 
coast is smaller by one order of magnitude than the rate of land-subsidence observed for the past 70 years (ShIMAZAKI, 1974b; KaSAHARA, 1975). During the 10 years after the former large interplate Nemuro-Oki event $(M=$ 7.9) in 1894 off eastern Hokkaido, a recovery of land-subsidence amounting to $40 \mathrm{~cm}$ was observed in the tidal record at Hanasaki (SHIMAZAKI, 1974b; Kasahara, 1975). On the basis of these facts, Shimazaki (1974b) and KASAHARA (1975) suggested that an aseismic faulting at the deeper half of the interface will follow the mainshock with a time-constant of about 10 years.

Geomorphological data on the Pacific coast of Tohoku require that a recovery of land-subsidence must occur also on the southern Sanriku. The southern Sanriku is a famous Rias coast and it had been generally said that marine terraces poorly develop on the Rias coast. However, recent geomorphological studies shows that marine terraces are often found on the Rias coast (Yoshikawa, 1964). Along the several bays on the southern Sanriku, well deposited marine terraces have been found with the altitude $20-90 \mathrm{~m}$ above the present sea level (IshiKaWA, 1964; MIURA, 1966, 1968; WAKo, 1966) and these coastal terraces are considered to be formed during the interglacial stages of high sea level in the late Quaternary period (MruRA, $1966,1968)$. Since the mean sea level during the latest interglacial stage at $1.3 \cdot 10^{5}$ years B.P. does not much differ from the present one (MACHIDA and SuzukI, 1971), Pacific coast of Sanriku must have been slightly uplifted or, at least, stable for the past $1.3 \cdot 10^{5}$ years. If the southern Sanriku had been subsiding with the rate of 4 to $6 \mathrm{~mm} / \mathrm{yr}$ since the $1.3 \cdot 10^{5}$ years B.P., the marine terraces formed in the latest interglacial stage would have submurged at 500 to $800 \mathrm{~m}$ below the present sea level, which contradicts with that observed. This piece of evidence indicates that the recent land-subsidence along the southern Sanriku must be recovered by uplift in the future nevertheless the expected coseismic crustal deformation caused by the future shock will bring no recovery to the observed subsidence. A delayed aseismic faulting at the deeper plate interface proposed by SHIMAZAKI (1974b) and KASAHARA (1975) is one possible mechanism for the recovery.

At the time of the shock, the stress in the land area will increase slightly because the elastic rebound at the shallower part of the interface will load the deeper thrust zone to the landward as was pointed out by ShIMAZAKI $(1976,1978)$. Thus the change in local stress after large interplate earthquakes should be modified as indicated by the broken line in Fig. 13. This provides an explanation for postseismic activity in northern Japan and the duration time of postseismic activity in Tohoku is almost in concordance with the time-constant of recovery of interseismic crustal deformation (ca. 10 years) estimated by SHIMAZAKI (1974b) and KASAHARA (1975). 


\section{Conclusions}

Historical seismicity data in Tohoku and Hokkaido since the year 1850 show a spatial and temporal correlation between intraplate seismicity $(M \geq$ 6.0) and occurrence of large interplate earthquakes along the Japan and the Kuril trenches. Almost all the earthquakes in the continental lithosphere occurred landward of the rupture zones of large interplate earthquakes during the periods from the 50 years before and to the 10 years after their occurrence. A simple statistical test of correlation for the past 100 years shows that this correlation is significant at a 99.5 per cent confidence level. Only a group of intraplate events in the zone of middle Tohoku have no corresponding large interplate earthquake seaward of their epicentral locations. This suggests a possibility of occurrence of a large interplate event off the southern Sanriku coast. All the examined data, historic and recent seismicity off the Sanriku coast, and geodetic data, support this possibility. The location of rupture zone of the expected shock, the time of its occurrence and the source parameters of this shock are estimated on the basis of the seismicity gap, historic records of large earthquakes off the Sanriku coast, and the rate of underthrusting of the oceanic plate as deduced from the crustal deformation.

The preseismically active area corresponds to the area of predominant interseismic crustal deformation; thus we can understand the preseismic activity in term of the interaction between the plates. At the time of the expected shock, only the upper one third of the plate interface will elastically rebound; this results in almost no relieving of the strain accumulated in the land area. On the contrary, the elastic rebound at the shallower interface will load the deeper thrust zone landward of the rupture zone of the shock. Geomorphological evidence on the southern Sanriku coast requires that the observed land-subsidence along this coast must be recovered by uplift in the future. A delayed aseismic faulting at the deeper plate interface is one of the possible mechanisms for recovery and the time-constant of recovery is in concordance with the duration time of the postseismic activity in northern Japan.

\section{Addendum}

A large earthquake attacked the southern Sanriku coast on June 12, 1978 while the manuscript of this paper was revised. The magnitude of the shock was determined to be 7.4 by the Japan Meteorological Agency. The aftershock distribution determined by the microearthquake observation network of Tohoku University indicates that this event ruptured the plate 
interface just west of the expected shock in this study. There remains yet a possibility of occurrence of a large event off the southern Sanriku as discussed in this study.

I wish to express my gratitude to Profs. K. Mogi, T. Utsu, T. Rikitake, Dr. K. Shimazaki, and Mr. T. Kato for critical review of the manuscript. I also wish to thank Dr. K. Shimazaki for making available to me computer programs for the finite-element method, Mr. T. Kato for unpublished information on computation of the finite-element method, Miss A. Tamura for the bibliography of geomorphological data over Tohoku, Prof. Y. Ota for helpful comments, and Prof. T. Yoshii for the detailed map of the aseismic and volcanic fronts. I benefited with discussion with Dr. K. Ishibashi, Dr. K. Shimazaki, Profs. H. Kanamori, N. Fujii, H. Mizutani, Mr. T. Kato, and with the members in the laboratories of Profs. H. Takeuchi and S. Uyeda. The numerical computation was carried out on HITAC $8700-8800$ at the Computer Center of University of Tokyo (4539293001 and 7254523001).

\section{Appendix. A Possible Criterion for Forecasting the Land Area of High Seismic Risk}

One of the most basic problems of earthquake prediction is to forecast the area of high seismic risk. With regard to great interplate earthquakes along major plate boundaries, the purpose to forecast the zones that are likely to rupture in the near future has been, at least partly, achieved (FEDotov, 1965; Mogi, 1968, 1969; Sykes, 1971; Utsu, 1972, 1974a; Kelleher, 1972, Kelleher et al., 1973; ANDo, 1975a; Ishibashi, 1977). However, most difficult is to forecast the land area where severe intraplate shocks may threaten. So far, there has been almost no effective criterion for forecasting the land area of high seismic risk for such severe intraplate events.

The hypothesis on the spatial and temporal correlation between intraplate seismicity and occurrence of large interplate earthquakes proposed in this study and in SENo (1979) may provide a possible criterion for forecasting the land area of high seismic risk. The portion of the land area which is in the pre- or postseismic activity of any large interplate event is a candidate for the area of high seismic risk. That is, it is an area of the continental margin adjacent to the thrust zone of a forthcoming large interplate shock or of a large interplate shock which occurred during the past 10 years. This area should also be characterized predominantly by the interseismic crustal deformation, i.e., contraction perpendicular to trench axis and oceanward tilt. According to this criterion, the land areas of high seismic risk in the Japanese islands are shaded in Fig. 14. They are eastern Hokkaido, middle Tohoku, and central Honshu. Eastern Hokkaido satisfies this criterion because it is now in the postseismic stage of the 1973 Nemuro-Oki event or because there remains a possibility of occurrence of a large shock off eastern Hokkaido in or near the rupture zone of the Nemuro-Oki event (HATORI, 


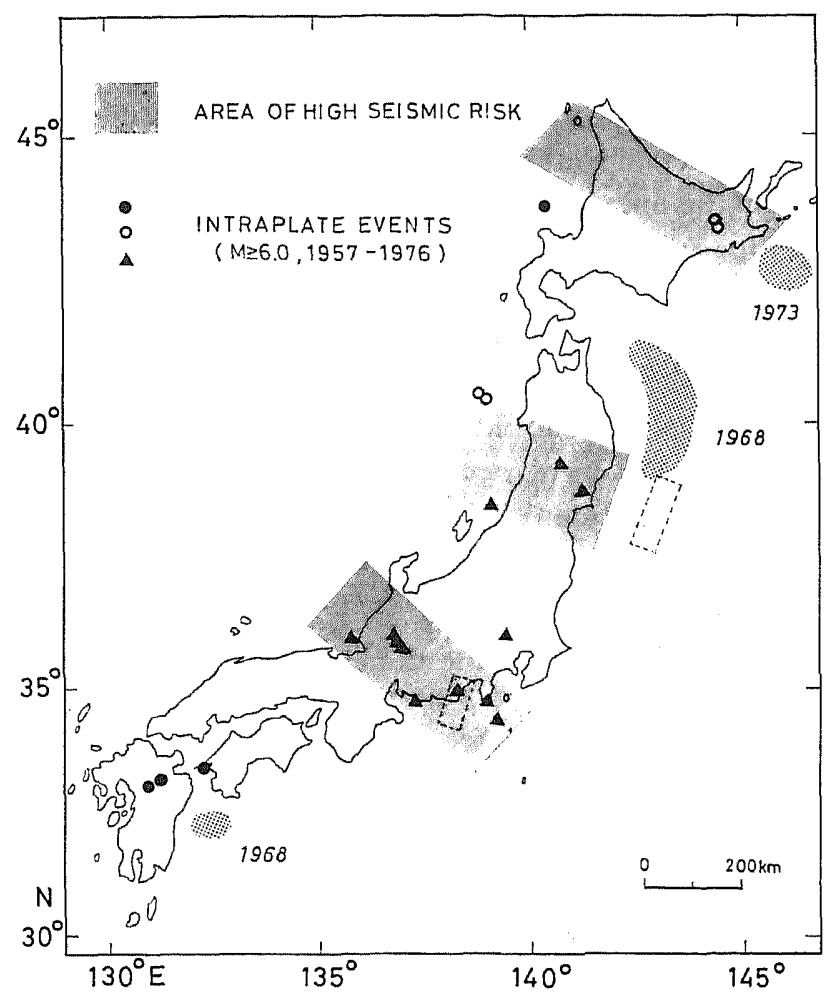

Fig. 14. Land areas of high seismic risk in the Japanese islands are shaded according to the criterion proposed in the text. Intraplate earthquakes for the last 20 years (1957-1976) are also shown in this figure. The triangles denote the intraplate events which cannot be correlated with any large interplate earthquake up to the present. The open and closed circles denote the intraplate events which can be regarded as preseismic and postseismic activity of recent large interplate earthquakes, respectively. The rupture zones of recent large interplate events and of expected large events are also shown.

1974b; Aвe and Yokoyama, 1974; Shimazaki, 1974b). Central Honshu, including the Tokai, Chubu, Hokuriku, Izu districts, is neighboring the expected rupture zone of a future great event off Tokai (ANDo, 1975a; IsHIBASHI, 1977) in the direction of the relative plate motion (SENO, 1977b). The middle Tohoku, including Miyagi, Yamagata, Akita, Niigata, Fukushima, and Iwate prefectures, is sited at the landward of the expected rupture zone of a future large event off the southern Sanriku coast as discussed in the present study. It should be noted that, as revealed by the geodetic work, these three areas coincide with the most highly deformed areas in Japan characterized by the interseismic crustal deformation. In Fig. 
14, intraplate earthquakes of magnitude 6.0 and above for the last 20 years (1957 to 1976) are also indicated. Those denoted by the solid triangles are the earthquakes which can not be correlated with any large interplate earthquake up to the present; they probably would be correlated with future large events. Those denoted by the open or solid circles are the events that can be regarded as the preseismic or postseismic activity of recent large interplate earthquakes, respectively. Intraplate seismicity in southwest Japan is significantly high in the shaded zone in central Honshu, which is discussed extensively by Seno (1979). This activity is probably the preseismic activity of a great future event off Tokai. It should, however, be noted that a certain number of intraplate earthquakes have occurred with no apparent correlation with occurrence of large interplate earthquakes, although the number of such events is quite few. It should also be noted that there are the regions which are difficult to be correlated with any specific rupture zone along the plate boundary; for example, Toyama, Niigata, Nagano prefectures are located far inlandward from the junction among the Izu-Bonin, Japan, and Ryukyusouthwest Japan arcs, thus these areas may not be correlated with any specific thrust zone. Kyushu is also a region difficult to apply the criterion proposed in this study, because moderate to large interplate eathquakes occur intermittently in the Hyuganada area off southern Kyushu, although three intraplate earthquakes in Fig. 14 in and near Kyushu may be regarded as the postseismic activity of the 1968 Hyuganada event $(M=7.5)$ (SENo, 1979). Therefore, the map of seismic risk in Fig. 14 should not be used definitely as a measure of seismic risk. Though this map provides a criterion for selecting areas of high priority for intsrumentation of various type to catch intraplate events in the near field, the areas presented are still wide; thus in order to set effectively a network of instruments, it is necessary to refer to other available informations such as the map of Quaternary active faults, characteristics of occurrence of earthquakes in each local region, pattern of the strain accumulation, in-situ stress measurements, and so on.

\section{REFERENCES}

Aве, K., Tectonic implications of the large Shioya-Oki earthquakes of 1938, Tectonophysics, 41, 269-289, 1977.

ABE, K. and I. YokoyAMA, An expected major earthquake off the coast of eastern Hokkaido, Rep. Coord. Comm. Earthq. Predict., 11, 45-50, 1974 (in Japanese).

AIDA, I., Simulations of large tsunamis occurring in the past off the coast of the Sanriku district, Bull. Earthq. Res. Inst., 52, 71-101, 1977 (in Japanese).

AKI, K., Generation and propagation of $G$ waves from the Niigata earthquake of June 16, 1964 (2) Estimation of earthquake moment, released energy, and stress-strain drop from the G wave spectrum, Bull. Earthq. Res. Inst., 44, 73-88, 1966.

ANDo, M., Possibility of a major earthquake in the Tokai district, Japan, and its pre-estimated seismotectonic effects, Tectonophysics, 25, 69-85, 1975a. 
ANDo, M., Source mechanisms and tectonic significances of historical earthquakes along the Nankai trough, Japan, Tectonophysics, 27, 119-140, 1975 b.

Coastal Movements Data Center, Tables and Graphs of Annual Mean Sea Level along the Japanese Coast 1894-1975, 1976.

Faculty of Science, Tohoku University, Microseismic activity in and near the Tohoku district, Rep. Coord. Comm. Earthq. Predict., 15, 19-29, 1976 (in Japanese).

Fedotov, S. A. Regularities of the distribution of strong earthquakes in Kamchatka, the Kurile Islands, and northern Japan, Tr. Acad. Sci. USSR, 36, 66-93, 1965.

FrTCH, T. J. and C. H. ScHolz, Mechanism of underthrusting in southwest Japan: A model of convergent plate interactions, J. Geophys. Res., 76, 7260-7292, 1971.

FusII, Y., Crustal movements associated with the 1933 Sanriku-Oki, Japan, earthquake, $J$. Geod. Soc. Japan, 23, 74-81, 1977 (in Japanese).

Fujita, N., Horizontal displacement vectors in Kanto and Chubu district, Rep. Coord. Comm. Earthq. Predict., 10, 64-67, 1973 (in Japanese).

HARADA, T. and N. ISAWA, Horizontal deformation of the crust in Japan-Result obtained by multiple fixed stations, J. Geod. Soc. Japan, 14, 101-105, 1969 (in Japanese).

Harada, T. and A. KassaI, Horizontal strain of the crust in Japan for the last 60 years, $J$. Geod. Soc. Japan, 17, 4-7, 1971 (in Japanese).

HASEbe, K., N. Fujir, and S. UYeda, Thermal process under island arcs, Tectonophysics, 10, 335-355, 1970.

HAtori, T., Dimensions and geographyic distribution of tsunami sources near Japan, Bull. Earthq. Res. Inst., 47, 185-214, 1969.

HA TORI, T., Tsunami sources on the Pacific side in northeast Japan, Zisin, 27, 321-337, 1974a (in Japanese).

Hatori, T., Source area of the tsunami off the Nemuro Peninsula in 1973 and its comparison with the tsunami in 1894, Spec. Bull. Earthq. Res. Inst., 13, 67-76, 1974b (in Japanese).

HAtoRI, T., Tsunami magnitude and wave source regions of historical Sanriku tsunamis in northeast Japan, Bull. Earthq. Res. Inst., 50, 397-414, 1975 (in Japanese).

Hatori, T., Propagation of tsunamis from sources off the Pacific coast of northeast Japan, Bull. Earthq. Res. Inst., 51, 197-207, 1976 (in Japanese).

Honda, H., A. MAsatsuka, and M. Ichikawa, On the mechanism of the earthquakes and the stresses producing them in Japan and its vicinity, Geophys. Mag. Japan Meteorol. Agency, 33, 271-279, 1967.

ICHIKAWA, M., Re-analyses of mechanisms of earthquakes which occurred in and near Japan, and statistical studies on the nodal plane solutions obtained, 1926-1968, Geophys. Mag. Japan Meteorol. Agency, 35(3), 207-273, 1971.

Imamura, A., On the chronic and acute earth-tiltings in the Kii Peninsula; Jap. J. Astron. Geophys., 7, 31-45, 1929.

INOUYE, W., On the seismicity in the epicentral region and its neighbourhood before the Niigata earthquake, Kenshinziho, 29, 139-144, 1965 (in Japanese).

IsHiBASHI, K., Re-examination of a great earthquake expected in the Tokai district, central Japan-Possibility of the "Suruga Bay Earthquake," Rep. Coord. Comm. Earthq. Predict., 17, 126-132, 1977 (in Japanese).

IshikAwA, K., Coastal terraces and geomorphological developement of the Ojika Peninsula, Ann. Tohoku Geogr. Assoc., 16, 126-129, 1964 (in Japanese).

KANAMORI, H., Focal mechanism of the Tokachi-Oki earthquake of May 16, 1968: Contortion of the lithosphere at a junction of two trenches, Tectonophysics, 12, 1-13, 1971a.

KANAMORI, H., Seismological evidence for a lithospheric normal faulting-The Sanriku earthquake of 1933, Phys. Earth Planet. Inter., 4, 289-300, $1971 \mathrm{~b}$.

Kanamori, H., Mechanism of tsunami earthquakes, Phys. Earth Planet. Inter., 6, 346-359, 1972. 
KANAMORI, H., The energy release in great earthquakes, J. Geophys. Res., 82, 2981-2987, 1977.

Kasahara, K., Aseismic faulting following the 1973 Nemuro-Oki earthquake, Hokkaido, Japan (a possibility), Pure Appl. Geophys., 113, 127-139, 1975.

KATO, T., Recent crustal movement in the Tohoku district for the period 1900-1965, Tectonophysics, 1979 (in press).

KELleHer, J., Ruptures zones of large South American earthquakes and some predictions, J. Geophys. Res., 77, 2087-2103, 1972.

Kelleher, J. and J. SAVINo, Distribution of seismicity before large strike slip and thrusttype earthquakes, $J$. Geophys. Res., 80, 260-271,.1975.

Kelleher, J., L. Sykes, and J. Oliver, Possible criteria for predicting earthquake locations and their application to major plate boundaries of the Pacific and the Caribbean, $J$. Geophys. Res., 78, 2547-2584, 1973.

MAchida, H. and M. Suzuki, A chronology of the late Quaternary period as established by fission track dating, Kagaku, 41, 263-270, 1971 (in Japanese).

MAtsudA, T., The Median Tectonic Line as an active strike-slip fault system, in The Median Tectonic Line, pp. 239-251, Tokai University Press, Tokyo, 1973 (in Japanese).

Miura, O., Coastal terraces and Rias along the Kesennuma bay, Miyagi prefecture, Ann. Tohoku Geogr. Assoc., 18, 116-122, 1966 (in Japanese).

Miura, O., Rias coast and coastal terraces of Sanriku, northeastern Japan, Geogr. Rev. Japan, 41, 732-747, 1968 (in Japanese).

MiYamura, S., Magnitudes of Japanese earthquakes in 1904-1906, presented at Joint IASPEI/ IAVCEI Scientific Assemblies, Darham, August, 1977, 1977.

Mogr, K., Some features of recent seismic activity in and near Japan (1), Bull. Earthq. Res. Inst., 46, 1225-1236, 1968.

Mogr, K., Some features of resent seismic activity in and near Japan (2), Activity before and after great earthquakes, Bull. Earthq. Res. Inst., 47, 395-417, 1969.

Mogr, K., Recent horizontal deformation of the Earth's crust and tectonic activity in Japan (1), Bull. Earthq. Res. Inst., 48, 413-430, 1970.

Nagumo, S., Activation mode of great submarine earthquakes along the Japanese Islands, in Publications for the 50th Anniversary of the Great Kanto Earthquake, 1923, 400 pp., Earthq. Res. Inst., Univ. of Tokyo, Tokyo, 1973.

OzAWA, I., Forecast of occurrences of earthquakes in the northwestern part of the Kinki district, Contrib. Geophys. Inst., Kyoto Univ., 13, 147-161, 1973.

Research Group for Microearthquakes, Faculty of Science, Tohoku University, Microseismicity maps of the Tohoku district for July-Dec., 1972, Rep. Coord. Comm. Earthq. Predict., 11, 51-55, 1974 (in Japanese).

SEno, T., Reccurrence times of great earthquakes in the seismotectonic areas along the Philippine Sea side coast of southwest Japan and south Kanto district, Zisin, 30, 25-42, 1977a (in Japanese).

Seno, T., The instantaneous rotation vector of the Philippine Sea plate relative to the Eurasian plate, Tectonophysics, 42, 209-226, $1977 \mathrm{~b}$.

SENO, T., Pattern of intraplate seismicity in southwest Japan before and after great interplate earthquakes, Tectonophysics, 1979 (in press).

SHIMAZAKI, K., Focal mechanism of a shock at the northwestern boundary of the Pacific plate: Extensional feature of the oceanic lithosphere and compressional feature of the continental lithosphere, Phys. Earth Planet. Inter., 6, 397-404, 1972.

SHIMAZAKI, K., Preseimic crustal deformation caused by an underthrusting oceanic plate, in eastern Hokkaido, Japan, Phys. Earth Planet. Inter., 8, 148-157, 1974a.

ShImAZAKI, K., Nemuro-Oki earthquake of June 17, 1973: A lithospheric rebound at the 
upper half of the interface, Phys. Earth Planet. Inter., 9, 314-327, 1974b.

SHIMAZAKI, K., Intra-plate seismicity and inter-plate earthquakes: Historical activity in southwest Japan, Tectonophysics, 33, 33-42, 1976.

SHIMAZAKI, K., Correlation between intraplate seismicity and interplate earthquakes in Tohoku, northeastern Japan, Bull. Seismol. Soc. Am., 68, 181-192, 1978.

SHIoNo, K., Focal mechanisms of major earthquakes in southwest Japan and their tectonic significance, J. Phys. Earth, 25, 1-26, 1977.

Sugrmur A, A. and S. UyedA, In Island Arcs: Japan and Its Environs, 247 pp., Elsevier, Amsterdam, 1973.

SYKEs, L. R., Aftershock zones of great earthquakes, seismicity gaps, and earthquake prediction for Alaska and the Aleutians, J. Geophys. Res., 76, 8021-8041, 1971.

TAKagi, A. and T. Hirasawa, Seismicity distribution and focal mechanisms in the source region of tsunamis off the Sanriku coast, in Estimation of Damage Caused by Large Tsunamis along the Sanriku Coast, Research group for natural disasters, 1977 (in Japanese).

TAKEUCHI, $\mathrm{H}$. and $\mathrm{H}$. KANAMORI, Crustal deformations before and after great earthquakes and the mantle convection, Zisin, 21, 317, 1968 (in Japanese).

Tokyo Astronomical Observatory, Science Almanac (Rikanenpyo), Maruzen, Tokyo, 1977.

Tsumura, K., Investigation of mean sea level and its variation along the coast of Japan (Part 2) Changes in ground level at various places in Japan as deduced from tidal data and earthquake prediction, J. Geod. Soc. Japan, 16, 239-275, 1971.

Usamr, T., Descriptive Catalogue of Disaster Earthquakes in Japan, 327 pp., Univ. Tokyo Press, Tokyo, 1975 (in Japanese).

Usami, T. and O. Hamamatsu, History of earthquakes and seismology, in Seismology in Japan, ed. Y. SATO, Zisin, 20(4), 1-34, 1967 (in Japanese).

USAMI, T. and I. KAYANO, Relation between the magnitudes give by Kawasumi and J.M.A., Bull. Earthq. Res. Inst., 48, 923-933, 1970 (in Japanese).

UTsu, T., Seismic activity in Hokkaido and its vicinity, Geophys. Bull. Hokkaido Univ., 20, 51-75, 1968 (in Japanese).

UTsu, T., Large earthquakes near Hokkaido and the expectancy of the occurrence of a large earthquake off Nemuro, Rep. Coord. Comm. Earthq. Predict., 7, 7-13, 1972 (in Japanese).

Utsu, T., Space-time pattern of large earthquakes occurring off the Pacific coast of the Japanese islands, J. Phys. Earth, 22, 325-342, 1974a.

UTsu, T., Correlation between great earthquakes along the Nankai trough and destructive earthquakes in Western Japan, Rep. Coord. Comm. Earthq. Predict. 12, 120-122, 1974b (in Japanese).

WAKo, T., Newly found marine terrace deposits in Sendai Bay area, Ann. Tohoku Geogr. Assoc., 18, 135, 1966 (in Japanese).

YonekuRA, N. and M. ANDO, Crustal movement associated with great earthquakes in trench areas and topography, Kagaku, 43, 92-101, 1973 (in Japanese).

Yostrr, T., Proposal of the "aseismic front", Zisin, 28, 365-367, 1975 (in Japanese).

YoshIr, T., Structure of the earth's crust and upper mantle in Tohoku, northeast Japan, Kagaku, 47, 170-176, 1977 (in Japanese).

Yoshikawa, T., On the geomorphologic development of Rias coasts in the Japanese islands, Quat. Res., 3, 290-296, 1964 (in Japanese).

Yoshioka, N. and K. AвE, Focal mechanism of the Iwate-Oki earthquake of June 12, 1968, J. Phys. Earth, 24, 251-262, 1976. 